\title{
ANALISIS KESULITAN PEMAHAMAN KONSEP ALAT OPTIK PADA SISWA KELAS VIII SEMESTER GENAP SMP NEGERI 3 METRO TAHUN PELAJARAN 2012/2013
}

\author{
Fitriani \\ HRA Mulyani \\ Pendidikan Fisika FKIP Universitas Muhammadiyah Metro \\ E-mail: hramulyani@gmail.com
}

\begin{abstract}
Abstrack: The purpose of this research to know form of difficulties were experienced by students looked form cognitive domain and questionsettlement stage. The subject of this research was student of grade VIIIc of junior high school 3 Metro academic year 2012/2013 the total of 33 students. Data capture technique used essay test. Data analysis was done by qualitative by identification, tabulation, describtion, and interpretationsteep. Base on analysis can be knowed that the most dominant difficulties were looked from question settlement stage that was operated stage the rules or the laws as much as $73 \%$. Students difficulties were looked from coqtinive domain in ability stage such as knowledge, comprehension, application, and analysis. Difficulties in cognitive domain the most dominant wasexperienced by students are in analysis ability stage as much as 91\%. To overcome the difficulties, the teacher is adviced in order that learning the most important to physic concept are felt difficult, that are aplication stage and analysis.
\end{abstract}

PENDAHULUAN

Pendidikan

pada

hakekatnya adalah suatu proses

pembinaan perkembangan

manusia yang dilakukan secara sadar dan terencana. Pendidikan memiliki peranan penting dalam kemajuan suatu bangsa yaitu kemampuan bersaing dan penguasaan IPTEK. Ukuran kesejahteraan suatu bangsa yang dulunya diukur dari sumber daya alam atau modal fisik telah bergeser digantikan dengan modal intelektual dan pengetahuan. Disinilah pendidikan memainkan perannya, karena didalam pendidikan terdapat proses perubahan tingkah laku manusia yang bertujuan membangun manusia seutuhnya, yaitu manusia sehat jasmani dan rohani, memiliki rasa tanggung jawab kemasyarakatan, dan kebangsaan sebagai bangsa indonesia.

Banyak upaya yang dilakukan oleh pemerintah dalam usaha mencapai tujuan pendidikan diantaranya adalah pemenuhan sarana dan prasarana, peningkatan mutu guru melalui pendidikan dan latihan, penataran dan seminar pendidikan. Pada sistem pendidikan itu sendiri, pemerintah 
sangat gigih dalam mencari jalan terbaik untuk sistem pendidikan di Indonesia, diantaranya perubahan kurikulum pada berbagai aspek yaitu tujuan, kompetensi, struktur, program dan deskripsi materi pelajaran.

Perubahan kurikulum tidak akan banyak berarti jika perilaku dan cara guru mengajar tidak ada perubahan. Salah satu ciri dalam perubahan ini adalah bagaimana seorang guru dapat mempersiapkan program pembelajaran secara cermat, sehingga kegiatan pembelajaran terlaksana secara menarik, melibatkan siswa, sumber daya yang tersedia dan bermakna. Masalah yang sering ditemui dalam dunia pendidikan adalah rendahnya mutu pendidikan yang tercermin dari rendahnya rata-rata prestasi belajar siswa.

Belajar ialah suatu proses usaha yang dilakukan seseorang untuk memperoleh sesuatu perubahan tingkah laku yang baru secara keseluruhan, sebagai hasil pengalamannya sendiri dalam interaksi dengan lingkungannya sesuai pendapat Sardiman (2010:21). Kemungkinan siswa belajar atau mengalami perubahan tingkah laku dapat dilihat dari pengukuran/penilaian. Demikian juga dalam proses pembelajaran, dapat diketahui kedudukan siswa yang pandai, sedang dan kurang pandai dengan mengetahui hasil belajarnya. Proses belajar sedikitnya akan menempuh sejumlah tahapan, salah satunya yaitu mengenal dan memahami pengetahuan, termasuk memahami materi fisika.

Secara umum siswa merasa bahwa mata pelajaran fisika merupakan mata pelajaran yang sulit. Hal ini disebabkan pada sulitnya siswa dalam memahami materi yang disajikan pada saat proses belajar mengajar, meskipun guru telah berusaha menstranfer ilmu yang dimiliki dengan berbagai macam metode, tetapi karena adanya perbedaan karakteristik siswa dalam memahami materi sehingga menimbulkan penerimaan siswa pada materi yang disampaikan berbeda pula.

Faktor-faktor yang mempengaruhi proses pembelajaran dibagi menjadi faktor eksternal dan faktor internal. Menurut Nasution (2006:50), faktor-faktor yang mempengaruhi pemahaman siswa diantaranya: bakat untuk mempelajari sesuatu, mutu pengajaran, kesanggupan memahami pengajaran, ketekunan, waktu yang tersedia untuk belajar.

Faktor yang sangat mempengaruhi proses belajar dan pembelajaran siswa adalah faktor 
intern yang berupa kemampuan pemahaman materi yang dimiliki dan dikuasai oleh siswa. Apabila faktor intern dapat teratasi maka dapat memudahkan siswa dalam mengatasi kesulitan belajar dalam memahami pelajaran Fisika yang diberikan oleh guru sehingga dapat mencapai hasil yang sesuai dengan tujuan pembelajaran.

Indikasi kesulitan belajar yang terlihat dari data awal siswa yang belum mencapai kriteria ketuntasan minimum (KKM) adalah siswa salah dalam menjelaskan suatu pengertian, siswa salah menyebutkan fungsi bagian mata, siswa salah dalam menggambarkan cara kerja alat optik, serta tidak mampu menerapkan materi pembelajaran tersebut dalam kehidupan seharihari. Untuk itu perlu adanya pemikiran dan penelitian yang dapat memberikan masukan bagi guru, siswa dan pihak lainnya tentang "analisis kesulitan pemahaman konsep alat optik pada siswa kelas VIII semester genap SMP Negeri 3 Metro tahun pelajaran 2012/2013".

\section{METODE PENELITIAN}

Penelitian ini menggunakan pendekatan kualitatif, yaitu pendekatan yang dimaksudkan untuk menganalisis pemahaman konsep alat optik siswa kelas
VIII $^{\mathrm{C}}$ tahun pelajaran 2012/2013

semester genap SMP Negeri 3 Metro. Dalam penelitian kualitatif bukan mengkaji kebenaran teori, melainkan membangun teori berdasarkan data yang dikumpulkan.

Jenis penelitian ini adalah deskriptif sebagaimana menurut Arikunto (2005:234) menyatakan bahwa "penelitian deskriptif merupakan penelitian yang dimaksudkan untuk mengumpulkan informasi status suatu gejala yang ada, yaitu keadaaan gejala menurut apa adanya pada saat penelitian dilakukan”. Penelitian ini dilakukan untuk usaha membangun teori berdasarkan data yang dikumpulkan melalui data hasil penelitian bukan untuk menguji teori. Berdasarkan uraian diatas pelaksanaan penelitian ini hanya memaparkan, melukiskan, dan melaporkan keadaan suatu obyek atau peristiwa tanpa menarik kesimpulan umum.

Sampel dalam penelitian ini diambil berdasarkan teknik cluster random sampling yaitu teknik pengambilan sampel dengan cara dari 7 kelas diambil 1 kelas sebagai sampelnya. Pengambilan sampel 1 kelas tersebut dilakukan secara acak karena peneliti menganggap semua populasinya adalah sama atau homogen. Caranya dengan menuliskan 
nama-nama kelas tersebut pada sebuah kertas kemudian menggulung dan mengocoknya hingga terpilih 1 kelas sebagai sampel.

Penelitian ini menggunakan instrumen soal tes essay yang disusun berdasarkan materi yang telah diajarkan untuk mengukur penilaian ranah kognitif. Menurut Bloom (dalam Sudijono, 2009:49-52) menyatakan bahwa ranah kognitif adalah ranah yang mencakup kegiatan mental (otak). Untuk memperoleh hasil pengukuran data yang valid maka digunakanlah validitas isi yang berguna untuk menunjukkan sejauh mana instrumen tersebut mencerminkan isi yang dikehendaki sesui pendapat Arikunto (2006:168) , untuk mengetahui tingkat reliabilitas alat ukur sesuai dengan pendapat Arikunto (2006:178) bahwa "Sesuatu instrumen cukup dapat dipercaya untuk digunakan sebagai alat pengumpul data karena instrumen itu sudah baik".Setelah data yang diperlukan terkumpul melalui metode tes kemudian data tersebut diidentifikasi, diklasifikasikan berdasarkan tahap kesulitan yang ingin diketahui, ditabulasikan, dideskripsikan hasilnya, menginterpretasikan dan kemudian menarik kesimpulan. Analisis data dilakukan dengan melihat lembar jawaban siswa.

\section{HASIL DAN PEMBAHASAN}

Bentuk-bentuk kesulitan yang dialami siswa pada tiap tahap kemampuan siswa dalam menyelesaikan soal alat-alat optik.

1. Kesulitan siswa ditinjau dari tahap menyelesaikan soal, tahap menyelesaikan soal ini hanya berlaku untuk soal hitungan, jadi hanya soal no. 6 dan 9. Yang terdapat pada tabel berikut:

Tabel 1. Siswa yang mengalami kesulitan ditinjau dari tahap menyelesaikan soal alat optik.

\begin{tabular}{|c|l|c|l|c|c|c|}
\hline No & $\begin{array}{c}\text { Tahap-tahap } \\
\text { menyelesaikan } \\
\text { soal }\end{array}$ & $\begin{array}{c}\text { No } \\
\text { So } \\
\text { al }\end{array}$ & $\begin{array}{c}\text { Bentuk } \\
\text { kesalahan }\end{array}$ & $\begin{array}{c}\text { Jumlah } \\
\text { siswa yang } \\
\text { mengalami } \\
\text { kesulitan }\end{array}$ & $\begin{array}{c}\text { Rata- } \\
\text { rata } \\
\text { Persen } \\
\text { tase } \\
(\%)\end{array}$ \\
\hline & $\begin{array}{l}\text { Menyusun apa } \\
\text { yang diketahui } \\
\text { dan apa yang } \\
\text { ditanya. Bentuk } \\
\text { kesulitan dalam } \\
\text { keadaan ini }\end{array}$ & 6 & $\begin{array}{l}\text { Siswa } \\
\text { mengalami } \\
\text { kesulitan dalam } \\
\text { menuliskan } \\
\text { lambang dan } \\
\text { satuan yang }\end{array}$ & 19 & $\begin{array}{c}\% \\
\%\end{array}$ & $61 \%$ \\
\hline
\end{tabular}




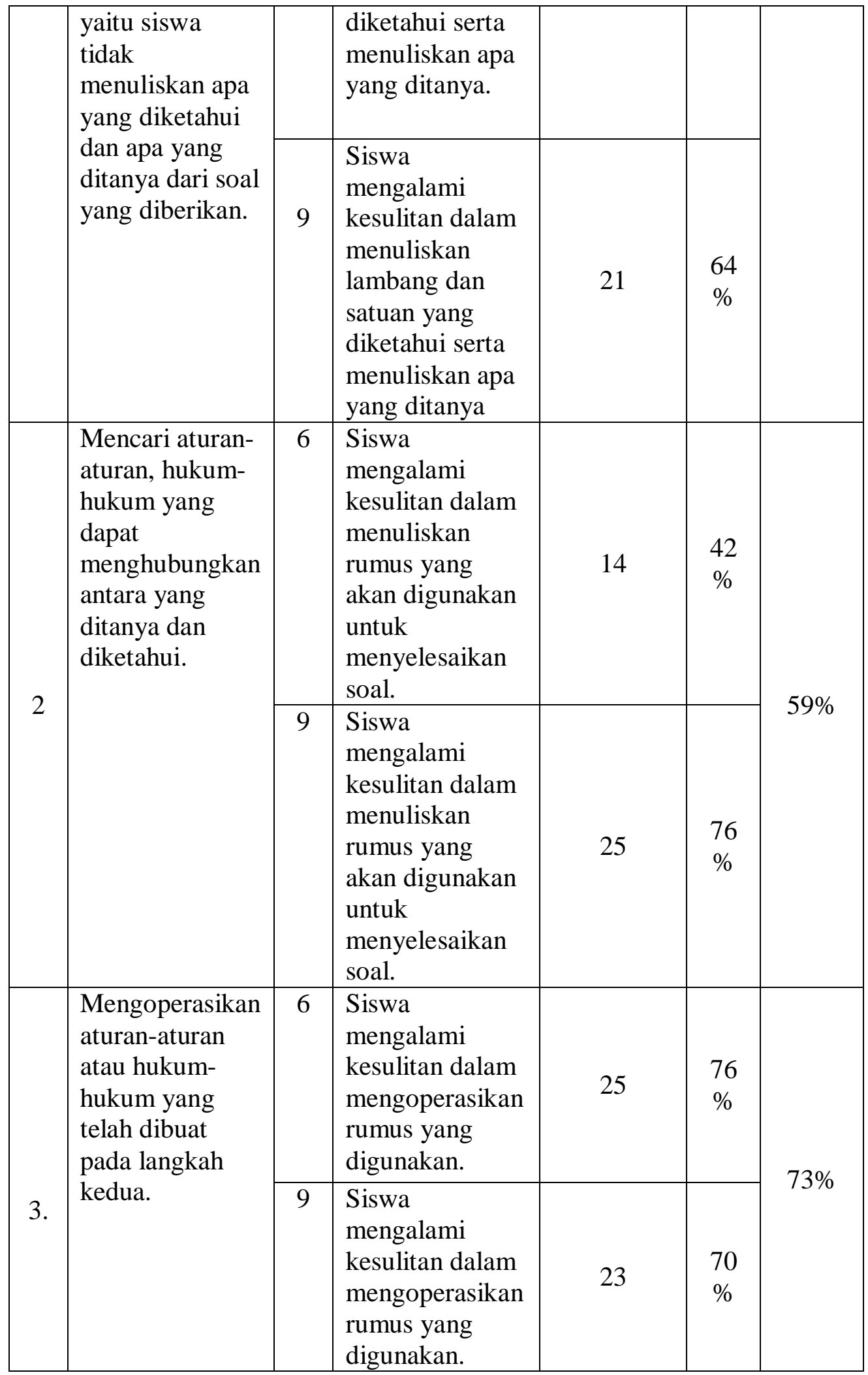


Siswa yang mengalami kesulitan

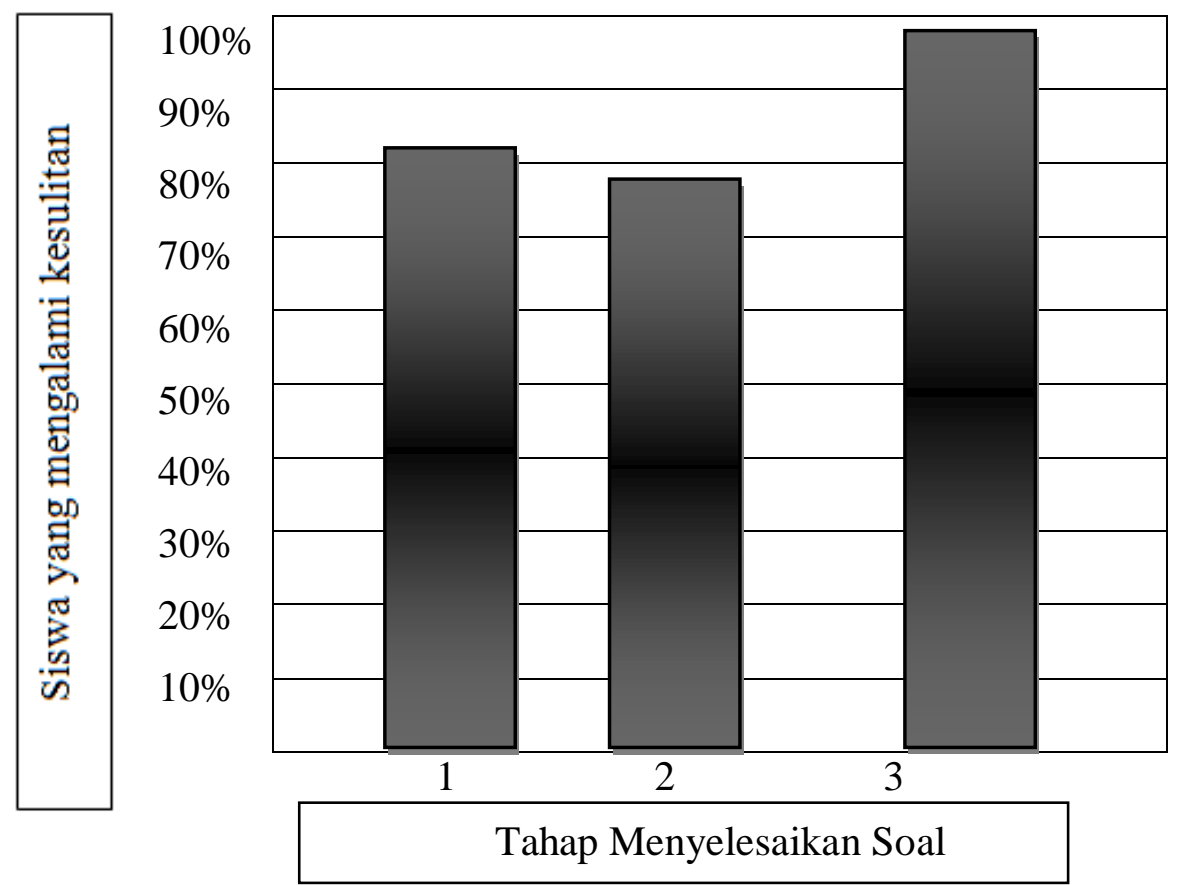

\section{Gambar 1 : Diagram siswa yang kesulitan ditinjau dari tahap menyelesaikan soal alat optik.}

Keterangan :

1 = Menyusun apa yang diketahui dan apa yang ditanya.

2 = Mencari aturan-aturan, hukum-hukum yang dapat menghubungkan antara yang ditanya dan diketahui.

3 = Mengoperasikan aturan-aturan atau hukum-hukum yang telah dibuat pada langkah kedua

2. Kesulitan siswa ditinjau dari aspek kognitif, terdapat pada tabel berikut:

Tabel 2. Kesulitan siswa dilihat dari asapek kognitif.

\begin{tabular}{|c|c|c|c|c|c|c|}
\hline No & $\begin{array}{c}\text { Tahap } \\
\text { Kemampu } \\
\text { an }\end{array}$ & $\begin{array}{c}\text { No } \\
\text { soa } \\
1\end{array}$ & $\begin{array}{c}\text { Bentuk kesulitan } \\
\text { pemahaman konsep }\end{array}$ & $\begin{array}{c}\text { jml } \\
\text { sisw } \\
\text { a }\end{array}$ & $\%$ & $\begin{array}{c}\text { Rata- } \\
\text { rata } \\
\text { Persent } \\
\text { ase } \\
\text { siswa }\end{array}$ \\
\hline \multirow{2}{*}{1} & 1 & $\begin{array}{l}\text { Siswa mengalami } \\
\text { kesulitan dalam } \\
\text { mengingat pengertian daya } \\
\text { akomodasi sebagai fungsi } \\
\text { mata sebagai alat optik }\end{array}$ & 9 & 27 & \\
\cline { 2 - 6 } & 5 & $\begin{array}{l}\text { Siswa mengalami } \\
\text { kesulitan dalam mengingat } \\
\text { aplikasi alat optik dalam }\end{array}$ & 4 & 12 & 20 \\
\hline
\end{tabular}




\begin{tabular}{|c|c|c|c|c|c|c|}
\hline & & & kehidupan sehari-hari & & & \\
\hline & & 8 & $\begin{array}{lr}\begin{array}{l}\text { Siswa } \\
\text { kesulitan }\end{array} & \text { mengalami } \\
\text { menjelaskan } & \text { dalam } \\
\text { kacamata } & \\
\end{array}$ & 7 & 21 & \\
\hline \multirow[b]{2}{*}{2} & \multirow[b]{2}{*}{$\mathrm{C} 2$} & 2 & $\begin{array}{l}\text { Siswa } \\
\text { kesulitan }\end{array} \begin{array}{l}\text { mengalami } \\
\text { menyebutkan bagian dan } \\
\text { fungsi dari bagian mata. }\end{array}$ & 15 & 45 & \multirow[b]{2}{*}{50} \\
\hline & & 7 & $\begin{array}{l}\text { Siswa mengalami } \\
\text { kesulitan dalam } \\
\text { menjelaskan prinsip kerja } \\
\text { microskop yang ditandai } \\
\text { kurang tepatnya siswa } \\
\text { dalam menjelaskan prinsip } \\
\text { kerja dari microskop } \\
\text { tersebut }\end{array}$ & 18 & 54 & \\
\hline \multirow{3}{*}{3} & \multirow{3}{*}{$\mathrm{C} 3$} & 3 & $\begin{array}{l}\text { Siswa mengalami } \\
\text { kesulitan untuk } \\
\text { menggambarkan jalannya } \\
\text { sinar pada retina untuk } \\
\text { penderita miopi setelah } \\
\text { menggunakan kacamata } \\
\text { berlensa cekung }\end{array}$ & 23 & 70 & \multirow[b]{3}{*}{78} \\
\hline & & 4 & $\begin{array}{l}\text { Siswa mengalami } \\
\text { kesulitan dalam mengingat } \\
\text { contoh aplikasi alat optik } \\
\text { dalam kehidupan sehari- } \\
\text { hari }\end{array}$ & 25 & 76 & \\
\hline & & 10 & $\begin{array}{lr}\text { Siswa } & \text { mengalami } \\
\text { kesulitan dalam } \\
\text { menggambarkan diagram } \\
\text { sinar pembentukan } \\
\text { bayangan pada lup untuk } \\
\text { mata } \quad \text { berakomodasi } \\
\text { maksimum. }\end{array}$ & 29 & 88 & \\
\hline \multirow[t]{2}{*}{4} & \multirow[b]{2}{*}{$\mathrm{C} 4$} & 6 & $\begin{array}{l}\text { Menghitung besarnya } \\
\text { kekuatan lensa (p) dan } \\
\text { titik jauh mata (s). }\end{array}$ & 31 & 94 & \multirow[b]{2}{*}{91} \\
\hline & & 9 & $\begin{array}{l}\text { Menghitung } \\
\text { kekuatan lensa (p) dan } \\
\text { titik jauh mata (s). }\end{array}$ & 29 & 88 & \\
\hline
\end{tabular}




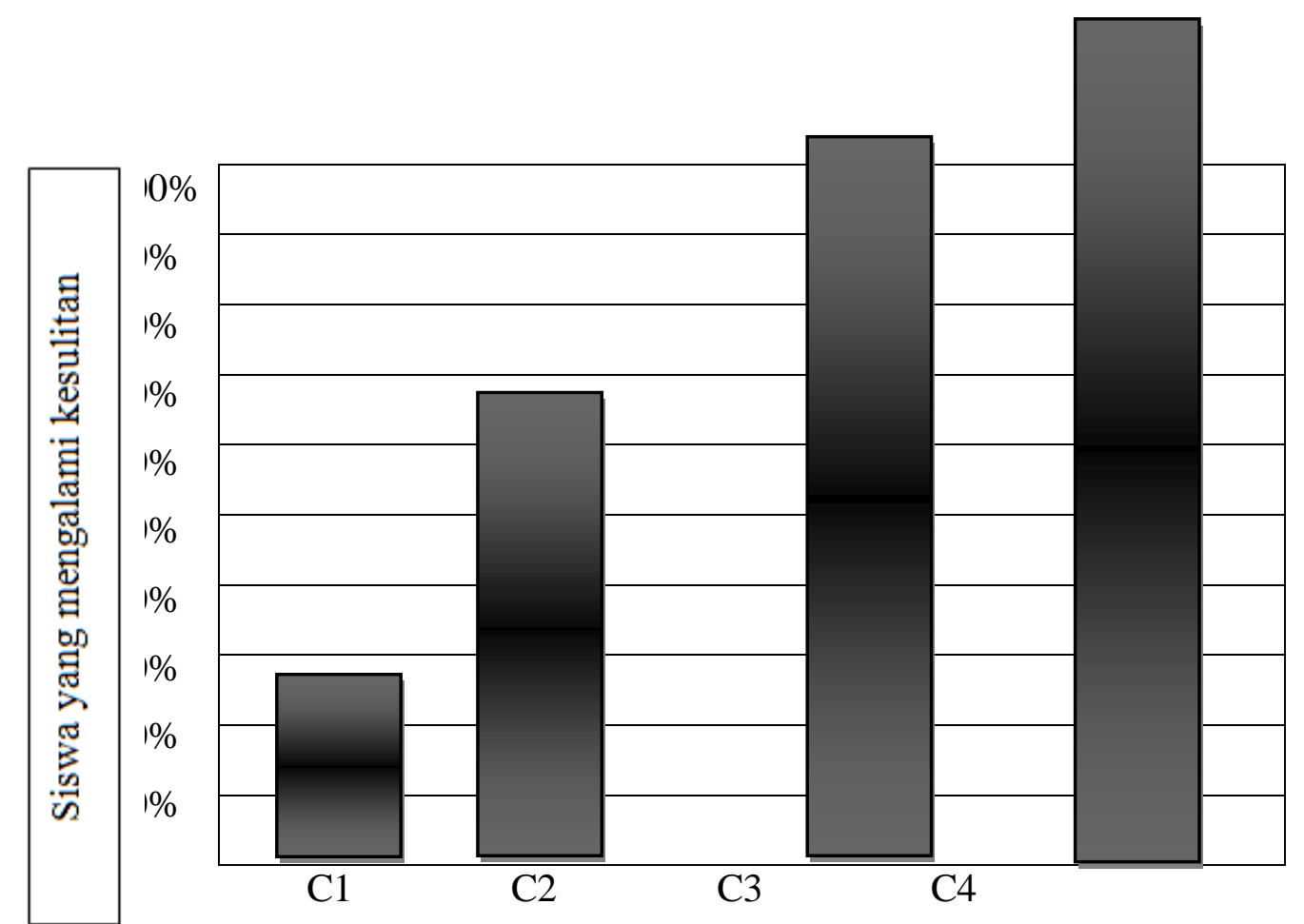

Gambar 2: Siswa yang mengalami kesulitan dilihat dari ranah kognitif.

Keterangan:

Pada ranah C1 siswa yang mengalami kesulitan sebanyak 20\% Pada ranah C2 siswa yang mengalami kesulitan sebanyak 50\% Pada ranah C3 siswa yang mengalami kesulitan sebanyak 78\% Pada ranah C4 siswa yang mengalami kesulitan sebanyak $91 \%$

Dari tabel tersebut dapat diketahui bentuk-bentuk kesulitan yang dialami oleh siswa yang ditinjau dari tahap menyelesaikan soal, bentukbentuk kesulitan tersebut adalah sebagai berikut:

a. Menyusun apa yang diketahui dan apa yang ditanya. Bentuk keadaan ini yaitu siswa mengalami kesulitan dalam menuliskan lambang dan satuan yang diketahui serta menuliskan apa yang ditanya. Siswa yang mengalami kesulitan pada tahap ini sebanyak $61 \%$.

b. Mencari aturan-aturan, hukum-hukum yang dapat menghubungkan antara yang ditanya dan diketahui. Siswa mengalami kesulitan dalam menuliskan rumus yang akan digunakan 
untuk menyelesaikan soal.

Siswa yang mengalami kesulitan pada tahap ini sebanyak 59\%.

c. Mengoperasikan aturanaturan atau hukum-hukum yang telah dibuat pada langkah kedua. Siswa yang mengalami kesulitan pada tahap ini sebanyak $73 \%$.

\section{KESIMPULAN}

Dari pembahasan secara deskriptif yang dikaitkan dengan tujuan penelitian maka hasil penelitian dapat disimpulkan sebagai berikut:

1. Kesulitan siswa memahami konsep yang ditinjau dari tahap penyelesaian soal yaitu banyak siswa yang masih mengalami kesulitan diantaranya:

a. Menyusun apa yang diketahui dan apa yang ditanya. Kesulitan siswa dalam tahap ini yaitu sebanyak $61 \%$.

b. Mencari aturan-aturan, hukum-hukum yang dapat menghubungkan antara yang ditanya dan diketahui. Kesulitan siswa dalam tahap ini yaitu sebanyak $59 \%$.

c. Mengoperasikan aturanaturan atau hukumhukum yang telah dibuat pada langkah kedua.

Kesulitan siswa dalam tahap ini yaitu sebanyak $73 \%$.

2. Tahap kesulitan yang dialami oleh siswa yang paling dominan yaitu Mengoperasikan aturanaturan atau hukum-hukum yang ada, yaitu sebanyak $73 \%$.

3. Kesulitan siswa ditinjau dari aspek kognitif, sebagai berikut:

a. Pada tahap kemampuan C1 (mengenal dan mengingat kembali), siswa yang mengalami kesulitan pada tahap ini sebanyak $20 \%$.

b. Pada tahap kemampuan C2 (memahami), siswa yang mengalami kesulitan pada tahap ini sebanyak 50\%.

c. Pada tahap kemampuan C3 (mengaplikasikan), siswa yang mengalami kesulitan pada tahap ini sebanyak $78 \%$.

d. Pada tahap kemampuan $\quad \mathrm{C} 4$ (menganalisis), siswa yang mengalami kesulitan pada tahao ini sebanyak $91 \%$.

4. Kesulitan pada aspek kognitif yang paling dominan dialami oleh siswa 


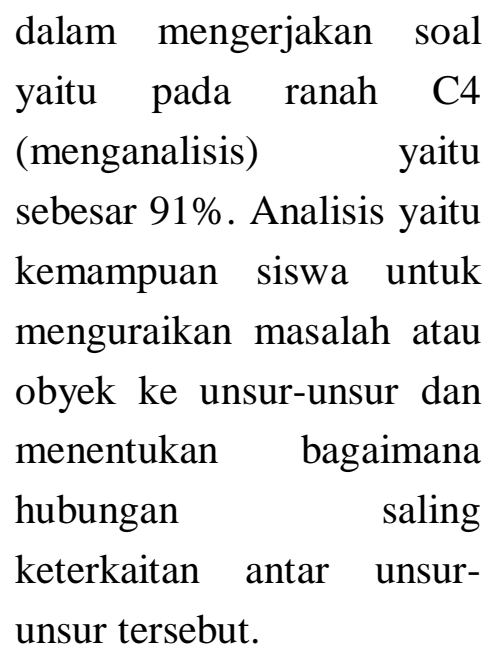

\section{DAFTAR PUSTAKA}

Arikunto, Suharsimi. 2005.

Dasar-dasar Evaluasi

Pendidikan. Edisi Revisi.

Jakarta: Rineka Cipta

2006.

Prosedur Penelitian Suatu

Pendekatan Praktek.

Nasution, S. 2006. Metode Pengajaran Nasional.

Bandung : Bumi Aksara.

Sardiman. 2011. Interaksi dan motifasi belajar mengajar.

Jakarta: raja grafindo persada

Sudijono, Anas. 2009. Pengantar

Evaluasi Pendidikan.

Jakarta : Raja Grafindo

Persada 